\title{
BLENDED LEARNING METHOD BASED ON LOCAL WISDOM AS A SPIRITUAL GUIDANCE HOLY TRINITY COMMUNITY IN DISTRICT BENGKAYANG
}

\author{
Priska Vasantan S.Si., Apt., M.MSI ${ }^{1)}$ \\ 1) STIM Shanti Bhuana, Bengkayang, West Kalimantan, Indonesia \\ E-mail: mariapriskavassantan@gmail.com
}

\begin{abstract}
Bengkayang is one of the districts the outermost in Indonesia. The district has limitations and underdevelopment in various fields, one of which is in the field of education. Writing this article aims to show that blended learning based on local wisdom is very helpful coaching Holy Trinity Community (HTC) in the district Bengkayang. It has been proven from previous studies, suggesting that coaching HTC with blended learning to be more flexible, effective and efficient. Blended learning has been applied HTC with a combination of conventional learning and e-learning in most areas in Indonesia. With the blended learning, the process of spiritual guidance becomes more flexible, effective and efficient so as to improve student in district Bengkayang.
\end{abstract}

Keywords: Blended learning, local wisdom

\section{INTRODUCTION}

In this era of globalization, the development of technology in education is very rapid so that the quality of education is increasing, but results of study students at one high school in district Bengkayang is very low because qualified teaching staff and infrastructure in high school is not adequate. It has been proven that when the early half of the new students, who are mostly from district Bengkayang difficult to learn. Education Fund Management Institution (LDPP) revealed that Bengkayang is one of outermost education district in west Borneo. When workshop west Borneo governor in 2010 also stated that the output of education in West Borneo is very low in terms of both the quality of teaching and education services are uneven. However, the District Education Office district Bengkayang stated that the quality of education in Bengkayang is very low so they have the highest priority targets for the next 5 years that is through programs and activities that support the promotion of education and achieving their vision and mission (Disdikbud, 2013).

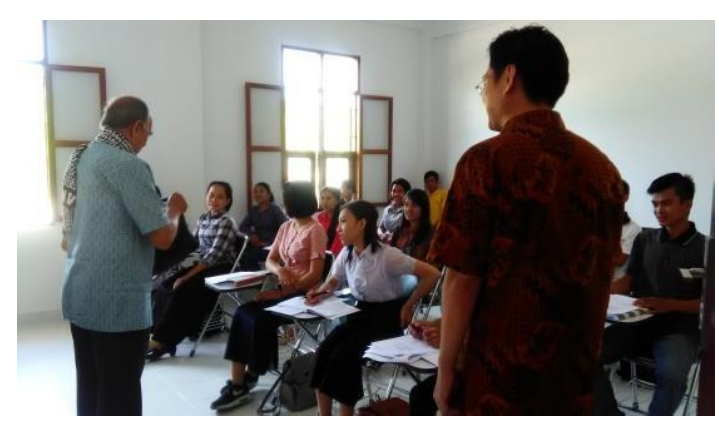

\section{METHODOLOGY}

This research uses the qualitative methods. The method of this research is in-depth observations and interviews and the interviewers were used the five student members and one faculty adviser Holy Trinity Community (HTC). HTC at the high school located in Bengkayang. This research also used data from the supporters of the thesis entitled "Implementation of e-Learning As a Means of Education for Spiritual Development Members HTC (Holy Trinity Community)," (2015).

\section{DISCUSSION}

Local wisdom in district Bengkayang

A problem in society will cause a response. Local knowledge is a positive response to deal with problems that occur. There are some local wisdom of district Bengkayang include:

First; the majority of people's livelihood in district Bengkayang is planters, farmers, rubber incisions. As farmers and planters, sometimes they care for and maintain the gardens and farm during the outcome of the gardens and farm. Harvest results and agricultural takes weeks or it may be monthly and yearly depending on what is planted. Another case with rubber incisions, initially they made cuts on rubber trees for rubber stream they wish to take and then they let a few hours (depending on the age rubber) latex container until the container is full. They did this many times and finally they sell to a result of nick rubber. Therefore wait for crop plantation/agriculture and nicks rubber takes quite a 
long time so they often have a habit of hanging out with friends so that they have a great kinship rope.

Farmers, has a culture that is called the new year rice, the party culture is done to celebrate the rice harvest so they celebrate it in a way coming from house to house. While growers produce corn, fruits, palm oil, and the others.

Second; utilization of wood available in nature often they use to craft the wood so they are very creative and quick in terms of carpentry. This is evident by the presence of some people who have a lot of work skills in carpentry.

Third; West Borneo has many rivers, so that small children are proficient to swim. Swimming is one of the entertainment for them, not just to clean the body, but also as a race and sports arena in the river. Examples swimming race, canoe race, and so forth.

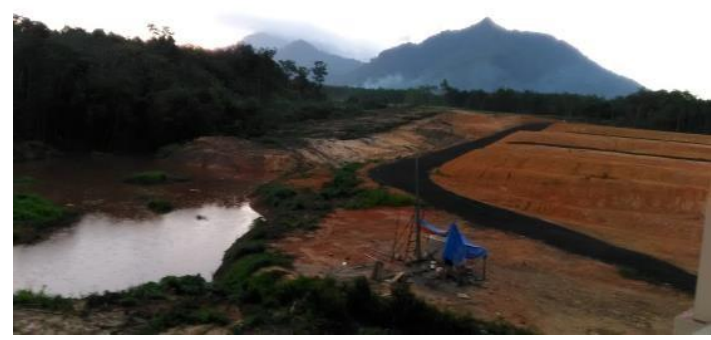

Local constraint of district Bengkayang

First; custom to wait for the harvest of agriculture, plantation, and rubber is hereditary in their lives. Vegetables and fish used for the daily needs can be obtained from the forest so that they have a lot of spare time in daily life so we can say they are spoiled by nature. However, often time it was used for gambling, drunk, party and chatting with unlimited time. According to Metropolis dated on September 29, 2016 stated that gambling high in West Borneo.

On the other hand, residents of the district Bengkayang there is a hard worker such as traders, collecting materials, processing of materials so that the time, energy and thought they were drained at work that cause them not to think about other aspects of life which even missed technological development. Sambas in society often call with urang nang kekapa'an, tehalle meaning time and energy severely depleted that it can not think of any other aspect of life.

Second; after harvest or to open up new land often they cut timber in the forest and burn the forest without regard to the effects such as landslides, flooding, air pollution, and so forth.

Third; using the river water is not hygienic for bathing, washing, relieving themselves even for a drink. The river water has high levels of metals in some places due to a gold mine so that the river water becomes turbid and high metal levels (Badan Geologi, 2016). High levels of metals affects the brain's ability to think. On the other hand, the existence of oil palm plantations surrounding the lack of water for bathing, washing and drinking so they have to walk far to find the river although the river is turbid. The majority of them do not have wells due to cost limitations and the lack of water because it is absorbed by the oil palm.
Fourth; passive mental contained on citizens Bengkayang hereditary making it less responsive to existing problems (Sambas people refer to it as 'Lenne Gilla') due to their need to exist in nature and habit of waiting for the harvest to spend free time in vain. They do not think about the dangers of the forest bare and air pollution when burned forest. On August through October 2015 have occurred that affect air pollution until at Kuching, Malaysia. Air pollution is caused by forest fires that often occur in previous years. Establishment of a beautiful environment for growing vegetables with vertikulur method is not performed. Vertikulur derived from the word 'vertical' and 'culture' which means the cultivation of plant by way of the story (Benny Sanusi, 2011
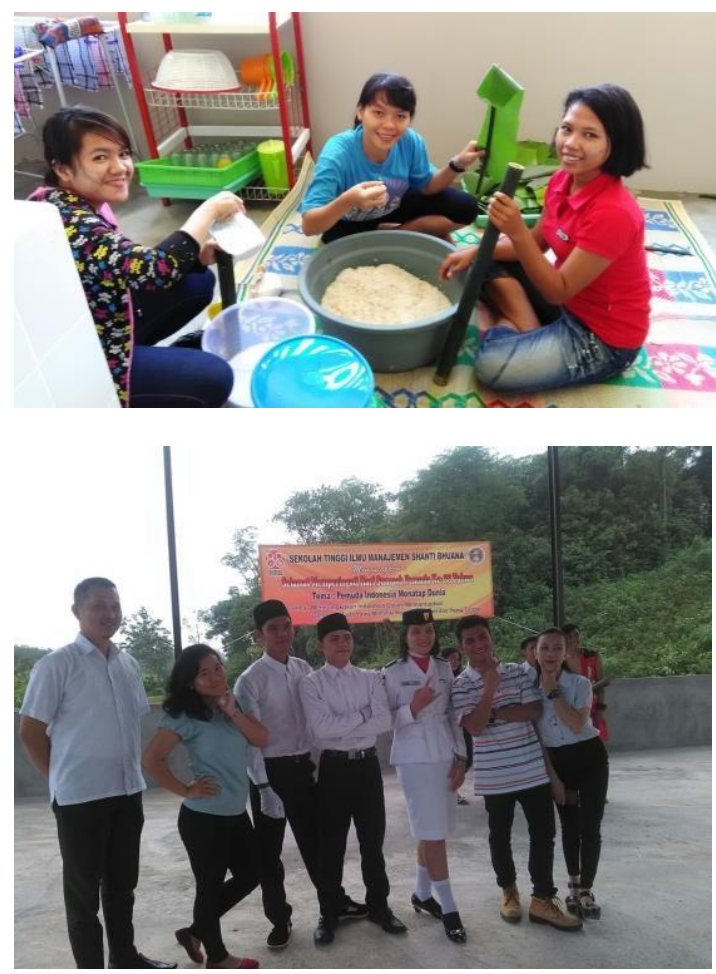

Blended learning method

Blended learning is a method that combines two methods of learning that e-learning and traditional learning classroom. However, both these learning methods have significant differences in the learning process which is a method that is online and offline.

Harvey Singh and Chris Reed, (2001) argues that blended learning is a learning method that uses more than one method that optimizes outcomes and costs. Therefore, Singh (2003) reaffirmed his opinion that:

Blended learning focuses on optimizing achievement of learning objectives by applying the "right" learning technologies to match the "right" personal learning style to transfer the "right" skills to the "right "person at the" right "time.

Thorne (2003) also expressed his opinion on the definition of blended learning that is:

"a way of meeting the challenges of tailoring learning and development to the needs of individuals byintegrating the innovative and technological advances offered by online learning with the 
interaction and participation offered in the best of traditional learning ".

Integrating the e-learning environment and is a fusion of traditional complementary. E-learning environment generates flexibility and efficiency that can not be found in traditional learning environment in the classroom. While the learning environment in the classroom to show a concept of learning faceto-face that support social interaction that is required in the learning process. Therefore, it can be said that blended learning is a combination of learning face to face and elearning are complementary.

Blended learning provides many advantages both in cost reduction, efficiency of time and place that is flexible so as to provide ease of understanding and motivation for each individual in learning face to face.

\section{Past research}

HTC is Holy Trinity Community which is one of the lay religious community. Coaching members HTC blended learning methods that have been performed worldwide with 100 respondents from various countries in 5 continents.

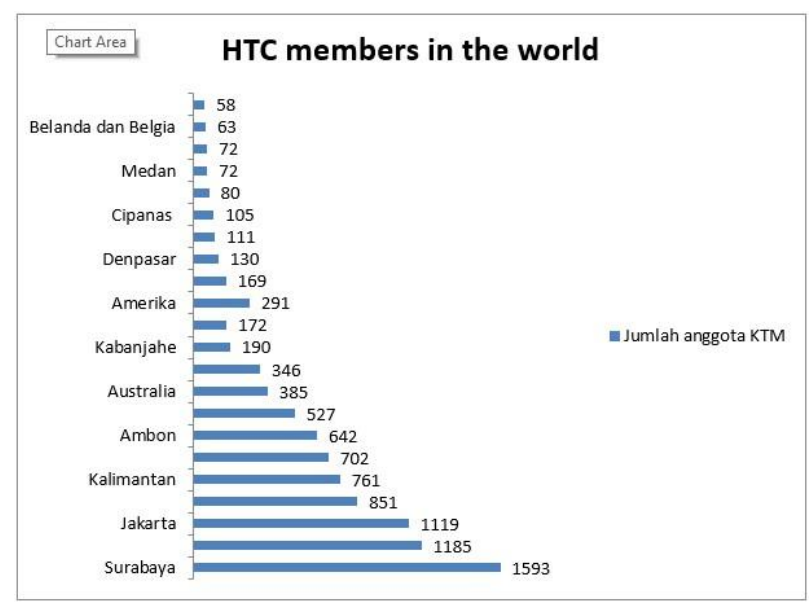

Thesis titled "Implementation of e-Learning As a Means of Education for Spiritual Development Members KTM (Holy Trinity Community)" produces as follows:

1. Aspects benefits, KTM respondents agree strongly agree $45.7 \%$ and $33.7 \%$.

2. Aspects of the use of e-learning as a complementary response states agree strongly agree $46.3 \%$ and $36.3 \%$.

TABLE I

RESULTS OF INTERVIEW

\begin{tabular}{|c|l|l|}
\hline No. & & \multicolumn{1}{|c|}{ Statement } \\
\hline 1. & $\begin{array}{l}\text { Benefits of } \\
\text { e-learning }\end{array}$ & $\begin{array}{l}\text { More familiar activities worldwide } \\
\text { KTM } \\
\text { Obtaining information up to date }\end{array}$ \\
\hline 2. & flexibility & $\cdot$ KTM easier to obtain any materials \\
\hline 3. & $\begin{array}{l}\text { Effective } \\
\text { and efficient }\end{array}$ & $\begin{array}{l}\text {. Time to upload and download can be } \\
\text { tailored to the needs of students } \\
\text { A place of learning in e-learning can } \\
\text { be done anywhere }\end{array}$ \\
\hline
\end{tabular}

\section{IV.CONCLUSIONS}

Blended learning is a combination of teaching methods between conventional e-learning and is already widely used in some areas in Indonesia, both in the field of education, spiritual formation, and so forth, for example, HTC spiritual development that has lasted until today. But the spiritual development HTC with blended learning method is still used by members of HTC in Bengkayang because of the results of in-depth interviews at 5 HTC members stated that they had never done before e-learning.

District Bengkayang is an area located on the border between Malaysia and West Borneo. However, Bengkayang has a quality education is minimal so it requires more time to understand and learn. From observations and in-depth interviews of five student members HTC and 1 builder HTC in a high school Bengkayang, they pointed out that the presence of blended learning then they are more easily expand their horizons and their knowledge that they can not get in a conventional classroom with downloading materials and obtain more information without thinking about time, space.

Blended learning method based on local wisdom to provide values, ethics and morals that can support the quality of spiritual development HTC Bengkayang. With local wisdom, the builder can customize according to the conventional coaching culture in district Bengkayang so as to bridge the coaching HTC Bengkayang.

Local wisdom is also easier flexibility of faculty adviser and member of HTC are nurtured. In terms of coaches, they are easier to socialize guidance material both online and conventional. Similarly, training material can be downloaded directly and more easily understood by members of HTC.

Efficiency and effectiveness of the time and place for this development is also seen from time and place that is not binding for the builder to enter the material and provide information for members HTC while abroad or in Indonesia without being bound by time and place. Similarly, the members of HTC in downloading, obtaining information and guidance to learn the material without being bound by time and place so that they can interact with supervisors, fellow HTC members who are far away though.

It can be said blended learning method based on local wisdom can enhance spiritual development in Bengkayang. It is advised to learning for students in Bengkayang.

\section{REFERENC \\ ES}

[1] (2016) Badan Geologi Homepage. [Online] Available: http://psdg.bgl.esdm.go.id/index.php?option=com content $\&$ view $=$ art icle\&id=41

[2] (2013) Disdikbud Homepage. [Online] Available:

[3] Priska Vasantan, "Implementation of e-Learning As a Means of Education for Spiritual Development Members HTC (Holy Trinity Community)," thesis, 2015, Binus University, Jakarta.

[4] (2015) Tribun Pontianak Homepage. [Online] Available: http://pontianak.tribunnews.com/2015/06/02/kalbar-miliki-palingbanyak-kandungan-mineral-logam

[5] LPDP, Daftar Daerah Tertinggal, Terdepan dan Terluar (Perbatasan) Tahun 2015. [Online] Available: http://www.lpdp.kemenkeu.go.id/wpcontent/uploads/2015/07/Daftar-Daerah-3T-2015.pdf 
[6] (2010) Disdik Homepage, Raker Gubernur KalBar. http://edoc.kalbarprov.go.id/berkas/DISDIK.pdf 
[7] (September 29, 2016) Metropolis Homepage, [Online] Available: http://www.pontianakpost.co.id/perjudian-kalbar-tinggi-disingkawang-ada-judi-meludah

[8] Thorne, K. (2003). Blended learning: How to integrate online and traditional learning, London: Kogan Page. [Online] Available: http://www.uady.mx/ contadur/seccip/articulos/libros online/ambien tesvirt/KoganPage2003BlendedLearning HowtoIntegrateOnlineandTr aditionalLearning2.pdf
[9] Andrew Higgins, (2014) Blended learning: How teachers balance the blend of online and classroom components. Journal of Information Technology Education: Research, 13, 121-140, [Online] Available: www.jite.org/documents/Vol13/JITEv13ResearchP121140Jeffrey0460.pdf

[10] Singh, H. (2003) "Building effective blended learning programs", Educational Technology, Vol. 43, No. 6, pp. 51-62.

[11] Singh, H. and Reed, C. (2001). A white paper: Achieving success with blended learning, retrieved November, 2014 [Online] Available: http://www.leerbeleving.nl/wbts/wbt2014/blend-ce.pdf 